\title{
METODE MAKE A MATCH: \\ Sebagai Upaya Meningkatkan Pemahaman dan Penguasaan Materi Bahasa Indonesia Siswa SMP
}

\author{
Engla Sabdatino Rahmadhani* \\ E-mail: esabdatino@gmail.com \\ *Program Studi Pendidikan Bahasa dan Sastra Indonesia, Universitas Riau
}

\section{Pengantar}

Pendidikan merupakan suatu usaha untuk membangun manusia seutuhnya yang berkualitas sesuai dengan yang diinginkan. Tujuan pendidikan adalah untuk mengembangkan potensi peserta didik agar menjadi manusia yang beriman dan bertakwa kepada Tuhan Yang Maha Esa, berakhlak mulia, sehat, berilmu, cakap, kreatif, mandiri, dan menjadi warga negara yang demokratis serta bertanggung jawab. Tujuan pendidikan di Indonesia belum tercapai secara maksimal, hal ini disebabkan karena kualitas pendidikan di Indonesia masih rendah. Berdasarkan survei tahunan yang dirilis PISA, kualitas pendidikan di Indonesia sangat memprihatinkan lantaran berada dalam daftar 10 terbawah dari seluruh negara di dunia. (Solopos.com).

Sistem pendidikan yang berubah-ubah akan berimbas kepada peserta didik ditambah dengan situasi Pandemi covid-19 saat ini membuat kualitas pendidikan turun. Siswa kehilangan kesempatan belajar sebagaimana mestinya. Sebelum diberlakukan peraturan pembelajaran tatap muka terbatas, proses pembelajaran berlangsung melalui Pembelajaran Jarak Jauh (PJJ). Hal ini tentu saja akan memberi dampak pada sistem pendidikan di Indonesia. Siswa yang selama ini santai belajar di rumah secara online akan kembali melakukan aktivitas pembelajaran di sekolah. Satu hal yang terbayang di pikiran siswa adalah proses pembelajaran yang membosankan.

Salah satu mata pelajaran yang dianggap membosankan bagi siswa adalah mata pelajaran bahasa Indonesia. Bahasa Indonesia merupakan mata pelajaran yang membutuhkan pemahaman lebih. Penyajian materi yang monoton berupa teks bacaan saja menyebabkan siswa bosan. Siswa yang mengalami kebosanan 
mengabaikan penjelasan dari guru dan melakukan kegiatan di luar pembelajaran, misalnya berbicara atau bermain dengan siswa lain sehingga konsep yang disajikan guru tidak sampai yang menyebabkan pemahaman siswa kurang.

Pemahaman adalah kemampuan seseorang dalam mengartikan, menafsirkan, menerjemahkan atau menyatakan sesuatu dengan caranya sendiri tentang pengetahuan yang pernah diterimanya. Kemampuan di tingkat pemahaman meliputi kemampuan mengklasifikasi, menggambarkan, mendiskusikan, menjelaskan, mengungkapkan, mendefinisikan, menunjukkan, mengalokasikan, melaporkan, mengakui, mangkaji ulang, melilih, menyatakan, dan menerjemahkan. (Uno dan Mohamad, 2015: 56).

Seorang guru dituntut untuk kreatif dan inovatif dalam memilih metode pembelajaran yang akan digunakan. Metode pembelajaran sangat menentukan efektifitas proses belajar mengajar. Metode pembelajaran adalah cara yang dianggap efisien yang digunakan oleh guru dalam menyampaikan suatu mata pelajaran tertentu kepada siswa, agar tujuan yang telah dirumuskan sebelumnya dalam proses kegiatan pembelajaran dapat tercapai dengan efektif. Pemberian metode pembelajaran harus disesuaikan dengan mata pelajaran yang sedang diberikan serta kondisi dan kebutuhan siswa dalam suatu kelas. Hal ini menjadi tugas guru sebagai fasilitator untuk memberikan metode pembelajaran yang tepat sehingga tujuan pembelajaran dapat tercapai dengan maksimal.

Metode pembelajaran yang inovatif mampu menciptakan pembelajaran aktif. Pembelajaran aktif (Active Learning) dikembangkan berangkat dari pandangan bahwa manusia adalah makhluk yang progresif, dinamis, aktif, dan kreatif. Ia dapat beradaptasi secara aktif dengan lingkungannya. Menurut Akbar dan Sriwiyana (2010: 237) pembelajaran aktif berarti pembelajaran yang terpusat pada siswa (student centered), yang dalam proses pembelajarannya siswa dilibatkan secara aktif untuk mengembangakan potensi yang ada pada dirinya. Siswa yang aktif dalam mengikuti kegiatan pembelajaran lebih paham konsep yang diberikan guru dari pada siswa yang tidak aktif. Aktif yang dimaksudkan adalah siswa berperan sebagai tokoh utama dalam pembelajaran sehingga terlibat langsung untuk melakukan hal-hal yang bersangkutan dengan proses pembelajaran. 
Salah satu metode pembelajaran yang tepat untuk meningkatkan pemahaman siswa dalam pembelajaran bahasa Indonesia adalah metode Make a Match. Metode ini dapat menciptakan suasana pembelajaran yang menyenangkan dan bermakna bagi siswa. Dengan metode ini, siswa diberikan pemahaman konsep menggunakan media konkret berupa kartu indeks yang dapat menciptakan suasana bermain yang menyenangkan. Pengalaman langsung yang menyenangkan ini menjadikan pembelajaran lebih bermakna bagi siswa. Metode Make a Match merupakan metode pembelajaran aktif yang dikemas menyenangkan dan melibatkan siswa langsung dengan bermain sambil belajar. Masing-masing siswa mencari pasangan jawaban/pertanyaan yang sesuai berdasarkan satu kartu yang diperolehnya. Siswa lebih aktif dan merasa tertarik untuk mencari pasangan yang tepat. Hal ini diharapkan dapat meningkatkan pemahaman siswa tentang konsep yang diberikan karena siswa mengalami langsung dengan metode yang menyenangkan.

\section{Hakikat Make a Match}

Suprijono (dalam Suprapta, 2020) menyatakan bahwa metode Make a Match merupakan metode mencocokkan kartu, siswa harus mencari pasangan dari kartu yang dimiliki dengan batas waktu tertentu mengenai suatu konsep pelajaran dalam suasana yang menyenangkan. Berdasarkan pernyataan tersebut, metode pembelajaran Make a Match digunakan untuk mengukur pemahaman siswa, yang dilakukan dengan cara mencocokkan kartu yang berisi pertanyaan dan jawaban dari materi pembelajaran yang sudah diajarkan. Metode pembelajaran Make a Match merupakan bagian dari strategi pembelajaran yang dapat meningkatkan kemampuan kognitif siswa. Metode pembelajaran tersebut mengajak siswa untuk dapat menghafal atau mengingat materi pelajaran dengan cara yang baru dan menyenangkan. Metode pembelajaran Make a Match dapat membantu kesulitan belajar siswa terutama dalam hal mengingat materi pelajaran. Proses pembelajaran dengan menggunakan metode pembelajaran lebih inovatif. Make a Match dapat berorientasi pada aktivitas belajar siswa menjadi lebih bermakna, lebih berorientasi pada keaktifan, serta membantu meningkatkan proses dan hasil belajar (Pratiwi, 2018). 


\section{Sarana Pendukung}

Tidak hanya metode yang diperlukan dalam pelaksanaan pembelajaran. Ada beberapa sarana pendukung yang juga menjadi unsur penting dalam perwujudan metode pembelajaran agar metode mampu digunakan dengan maksimal pada proses pembelajaran. Sarana pendukung tersebut adalah sebagai berikut.

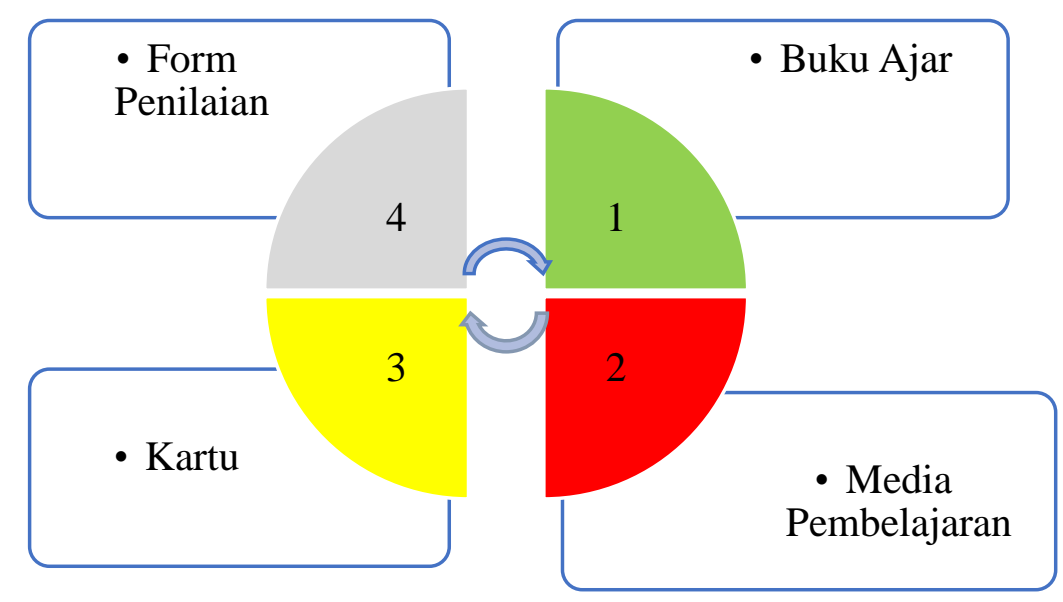

\section{Gambar 1. Sarana Pendukung Make a Match}

1. Buku Ajar, buku ajar merupakan sarana pendukung utama karena merupakan kunci dari pelaksanaan pembelajaran. Melalui buku ajar akan meminimalisir kesalahan dalam penyampaian materi oleh guru terkait teks prosedur karena buku ajar disusun oleh para ahli sebagai sarana pembelajaran yang intruksional.

2. Media Pembelajaran, media pembelajaran merupakan alat bantu proses belajar mengajar. Pemakaian media pembelajaran dalam proses belajar mengajar dapat membangkitkan keinginan dan minat yang baru, membangkitkan motivasi dan rangsangan kegiatan dan bahkan pengaruhpengaruh psikologis terhadap siswa. Dalam proses pembelajaran ada pesan yang ingin disampaikan guru kepada siswa berupa materi pembelajaran. Pesan tersebut dapat berupa informasi yang mudah diserap oleh siswa, tetapi juga dapat berupa informasi yang abstrak atau sulit untuk dipahami. Saat pesan yang disampaikan tidak dapat diterima siswa, media menjadi solusi yang dapat menyampaikan pesan. 
3. Kartu, karena metode Make a Match merupakan metode pembelajaran yang menggunakan kartu sebagai medianya, tentunya kartu merupakan sarana pendukung dalam pelaksanaan alternatif ini pada mata pelajaran bahasa Indonesia. Kartu berisi pertanyaan dan jawaban dari materi pembelajaran yang sudah diajarkan.

4. Form Penilaian, dalam pelaksanaan pembelajaran, form penilaian merupakan salah satu sarana penting untuk melihat perkembangan dan tingkat ketercapaian tujuan pembelajaran.

\section{Tindakan Solutif}

Berikut tahapan implementasi pembelejaran bahasa Indonesia menggunakan metode Make a Match.

1. Guru menyiapkan kartu berisi soal-soal yang berhubungan dengan materi yang akan diajarkan dan Sebagian kartu yang lain adalah kartu jawaban.

2. Guru membagikan kartu soal dan kartu jawaban kepada siswa, setiap siswa mendapatkan satu buah kartu (kartu soal atau kartu jawaban).

3. Setiap siswa memikirkan soal atau jawaban yang telah dipegang.

4. Siswa mencari pasangan yang mempunyai kartu yang cocok dengan kartunya (kartu soal/kartu jawaban).

5. Setiap siswa yang dapat mencocokkan kartunya baik kartu soal maupun kartu jawaban dengan benar akan mendapatkan poin aatau hadiah.

6. Masing-masing pasangan soal dan jawaban menunjukkan hasil diskusinya di depan kelas.

7. Setelah satu babak selesai, kartu soal maupun kartu jawaban dikocok agar masing-masing siswa mendapatkan kartu yang berbeda.

\section{Simpulan}

Materi bahasa Indonesia merupakan materi yang tidak mudah. Bahasa Indonesia merupakan mata pelajaran yang membutuhkan pemahaman lebih. Penyajian materi yang monoton berupa teks bacaan saja menyebabkan siswa bosan. Siswa yang mengalami kebosanan mengabaikan penjelasan dari guru dan 
melakukan kegiatan di luar pembelajaran, misalnya berbicara atau bermain dengan siswa lain sehingga konsep yang disajikan guru tidak sampai yang menyebabkan pemahaman dan penguasaan materi siswa kurang.

Metode Make a Match dapat menciptakan suasana pembelajaran yang menyenangkan dan bermakna bagi siswa. Dengan metode ini, siswa diberikan pemahaman konsep menggunakan media konkret berupa kartu indeks yang dapat menciptakan suasana bermain yang menyenangkan. Pengalaman langsung yang menyenangkan ini menjadikan pembelajaran lebih bermakna bagi siswa. Metode Make a Match merupakan metode pembelajaran aktif yang dikemas menyenangkan dan melibatkan siswa langsung dengan bermain sambil belajar. Masing-masing siswa mencari pasangan jawaban/pertanyaan yang sesuai berdasarkan satu kartu yang diperolehnya.

\section{Referensi}

Akbar, S. \& Sriwijaya, H. (2010). Perkembangan Kurikulum dan Pembelajaran Ilmu Pengetahuan Sosial (IPS). Yogyakarta: Cipta Media.

Memprihatinkan! Kualitas Pendidikan Indonesia 10 Terbawah di Dunia (2019, September 4). Diakses pada 1 Desember 2021, dari berita online. https://www.solopos.com/memprihatinkan-kualitas-pendidikan-indonesia10-terbawah-di-dunia-1034654.

Mustafa, M. N., \& Zulhafizh. (2017). Building the Professionalism of Teachers as an Effort to Improve Education. In Husein, R, et al (Eds.), International Seminar and Annual Meeting 2017 Fields of Linguistics, Literature, Arts, and Culture, Medan, 516.

Mustafa, M. N., Hermandra, \& Zulhafizh. (2019). Teachers' Strategies to Design Media to Implement Communicative Leaning in Public Schools. Journal of Educational Sciences, 3(1), 13-24.

Pratiwi, Rina Hidayati. (2018). Metode Pembelajaran Make a Match Dan Pengaruhnya Terhadap Hasil Belajar Ipa. Jurnal Florea 5 (1).

Suprapta, Dewa Nyoman. (2020). Penggunaan Model Pembelajaran Make a Match Sebagai Upaya Meningkatkan Hasil Belajar Bahasa Inggris Siswa. Journal of Education Action Research 4(3).

Uno, H. B. \& Mohamad, N. (2015). Belajar dengan Pendekatan Pembelajaran Aktif Inovatif Lingkungan Kreatif Efektif Menarik. Jakarta: Bumi Aksara. 


\section{*Data Penulis}

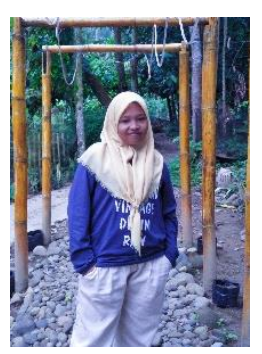

Engla Sabadatino Rahmadhani lahir di Panyakalan, 23 November 2002. Berasal dari Solok- Sumatera Barat. Pada tahun akademik 2020 - 2021, Ia melanjutkan studi pada strata satu Jurusan Pendidikan Bahasa dan Seni di Program Studi Pendidikan Bahasa dan Sastra Indonesia FKIP Universitas Riau melalui jalur SNMPTN, sekarang masih berstatus mahasiswa.

Kontak:

Hp/WA : 082174120264

Email : esabdatino@gmail.com / engla.sabdatino0601@student.unri,ac.id 